\title{
Kegiatan Membaca Pagi untuk Mengembangkan Kemampuan Oral Siswa Tunarungu
}

\section{Aliffian Fajar Rahman, Sulthon}

Universitas Negeri Malang

Email: aliffianfajor@gmail.com

bstrak: Dalam berkomunikasi dengan orang lain, anak tunarungu menggunakan bahasa isyarat dan bahasa oral. Namun, menggunakan bahasa oral tidaklah mudah. Untuk mengatasi hal tersebut, perlu dilaksanakan metode yang dapat meningkatkan kemampuan oral siswa tunarungu. Fokus penelitian ini
dalah: (1) pelaksanaan kegiatan membaca. (2) Hambatan kegiatan membaca. (3) Dampak kegiatan membaca bagi siswa tunarungu. Penelitian ini menggunakan metode kualitatif dengan jenis penelitian studi kasus. Hasil temuan peneliti ini meliputi: (1) proses pelaksanaan kegiatan membaca. (2) hambatan dalam pelaksanaan kegiatan membaca setiap pagi. (3) dampak kegiatan membaca bagi siswa tunarungu

Kata Kunci: Tunarungu, Kegiatan membaca, Oral

Abstract: In communicating with others, hearing impairment student use sign language and oral language. However, using oral language is not easy. To overcome this, it is necessary to implement methods that can improve the oral ability of students with hearing impairment. The focus of this research are: (1) the implementation of reading. (2) Barriers to reading. (3) Impact of reading activity for hearing impairment students. This research uses qualitative method with case study research. The findings of this esearch include. (1) the process of reading activity. (2) obstacles in the execution of reading activity very morning. (3) the impact of reading activity for Key Words: Hearing impairtment, Reading activity,

Pendidikan merupakan kebutuhan untuk setiap individu untuk mempersiapkan hidupnya di masa individu untuk mengembangkan dan meningkatkan potensi yang dimiliki Pendidikan merupakn hak bagi setiap individu. Tidak hanya mereka yang mak bagi kondisi normal saja, tetapi juga bagi mereka yan memiliki kebutuhan khusus. Hak atas pendidikan bagi anak berkebutthen khusus atau anak dengen hambatan diterangkan dalam UU No. 20 Tahun 2003 tentang Sistem Pendidikan Nasional Pasal 5 Ayat 2 , yaitu "Warga Negara yang memiliki kelainan fisik, emosional, mental, intelektual dan/atau sosial berhak memperoleh pendidikan khusus". Berlandaskan pad Undang-undang tersebut, dapat disimpulkan bahwa semua warga Negara Indonesia tanpa terkecuali, sepert anak berkebutuhan khusus (ABK) berhak memperoleh pendidikan yang layak. Anak berkebutuhan khusus salah satunya adalah anak tunarungu.

Tunarungu dapat diartikan sebagai suatu keadaan kehilangan pendengaran yang mengakibatkan seseorang tidak dapat menagkap berbagai rangsangan, terutama melalui indera pendengarannya (Somantri, 2012). Hal tersebut berdampak terhadap kehidupannya secara kompleks, terutama pada proses komunikasi mereka dengan orang lain. Menurut Geniof (2010) dam Ayudani, mengemukakan bahwa untuk berkomunikasi dengan orang lain, anak tunarungu menggunakan bahasa bibir atau bahasa isyarat. Namern

faktanya dalam kehidupan sehari-hari kebanyakan orang lain yang menjadi lawan berkomunikas anak tunarungu tidak mengerti akan bahasa isyarat, mereka cenderung lebih mengerti atau memaham apa yang disampaikan oleh anak tunarungu dengan menggunakan bahasa bibir. Bahasa bibir atau gerak bibir sering juga disebut sebagai oral.

Oral merupakan cara yang digunakan oleh anak tunarungu dalam berkomunikasi, baik denga sesama tunarungu maupun dengan orang lain yang tidak mengounakan bahasa isyarat atau Mera $j$ tidak menggunakan bahasa isyarat atau gerak jari (capi lebih menekankan pada pembacaan gerak bibir han tidek mudah unk ank ter dibung tick Salah satu cara anu metode yang dapat digny. Salah

SLB Eka Mandiri Kota Batu merupakan salah satu SLB di kota Batu. Terdapat siswa tunanetra, tunarungu, tunagrahita, tunadaksa, autis, hiperaktif, tunaganda da hampir lengkap dengan bermacam ketunaan tersebu Siswa tunarungu di SLB Eka Mandiri Kota Bat berkomunikasi dengan teman, guru, orang tua maupu orang lain menggunakan bahasa isyarat dan oral. $\mathrm{Ha}$ tersebut juga diajarkan dan dilatih setiap pagi. Sebelun memulai pelajaran, setiap pagi siswa dan sisw kegiatan membaca. Kegiatan membaca ini bertujuan untuk melatih kemampuan oral mereka. Penelilitian embaca setiap pagi pada siswa tunarungu di SLB Eka Mandiri Kota Batu.

\section{METODE}

Penelitian ini menggunakan pendekatan kualitatif. Menurut Bogdan dan Taylor (1975), dalam Moleong,
(2016) mengemukakan bahwa metodologi kualitatif sebagai prosedur penel deskriptif berupa kata-kata tertulis atau lisan dari orang-orang dan perilaku yang dapat diamati Menuru orang-orang dan perilaku yang dapat diamati. Menurut
mereka, pendekatan ini diarahkan pada latar dan mereka, pendekatan ini diarahkan pada latar dan
individu tersebut secara utuh dan langsung. Penelitian individu tersebut secara utuh dan langsung. Penelitian tujuan untuk mempelajari secara mendalam dengan tujuan untuk mempelajari secara mendalam dengan
mendeskripsikan kegiatan membaca pada siswa tunarungu. Jenis penelitian yang digunakan adalah studi kasus.

Peneliti merupakan instrumen kunci dalam penelitian kualitatif dan sekaligus pengumpul data penelitian. Kehadiran peneliti di lapangan mutlak diperlukan. Peneliti tidak dapat digantikan oleh yang lain. Oleh karena itu, peran peneliti di lapangan merupakan kunci keberhasilan, sehingga dalam pelaksanaannya dibutuhkan keseriusan dalam penelitian.

Data dalam penelitian ini diperoleh dari subyek yang disebut sumber data. Sumber data dalam penelitian ini yaitu hasil dari wawancara, observasi, dan dokumentasi. Wawancara dilakukan terhadap sumber yang dianggap memiliki informasi kuat tentang egiatan membaca di pagi hari bagi siswa tunarungu di SLB Eka Mandiri Batu, yaitu kepala sekolah, guru kelas, dan wali murid. Jenis wawancara yang digunakan dalam penelitian ini adalah wawancara tidak terstruktur (open ended interview). Pada jenis wawancara ini, peneliti tidak menggunakan panduan yang berisi pertanyaan sebagaimana yang telah disiapkan seperti pada wawancara terstruktur. Panduan wawancara yang digunakan hanya berisi garis-garis besar permasalahan yang akan ditanyakan. Sedangkan observasi dilakukan dengan cara mengamati secara langsung, dan peneliti terlibat secara penuh sebagai partisipan dalam kegiatan membaca yang dilakukan oleh siswa tunarungu di SLB Eka Mandiri Batu agar data yang didapat akurat. Oleh karena itu, tipe pengamatan yang digunakan adalah partisipan penuh (complete participant) Selama proses pengamatan atau observasi, peneliti dapat menggambarkan kondisi yang ada di lapangan secara langsung, kemudian dilaporkan dalam catatan lapangan dengan menulis setiap kegiatan yang telah dilakukan. Selain digunakan teknik wawancara dan observasi, digunakan pula teknik dokumentasi. Teknik ini digunakan sebagai pelengkap dari kedua teknik sebelumnya (wawancara dan observasi). Menurut
Sugiyono (2014), dokumen merupakan "catatan peristiwa yang sudah berlalu, dokumen bisa berbentuk tulisan, gambar, atau karya-karya monumental dari seseorang". Dokumen yang digunakan oleh peneliti meliputi foto kegiatan, buku bacaan yang digunakan, dan dokumen lain yang mendukung pengumpulan data bagi peneliti.

Langkah selanjutnya setelah pengumpulan data yaitu menganalisis data. Analisis data dalam penelitian kualitatif adalah proses sistematis untuk mencari dan mengatur transkip wawancara, catatan lapangan, dan materi-materi lain yang penting untuk dilaporkan kepada oranglain sebagai temuan penelitian (Ulfatin, 2014). Ada tiga tahapan dalam analisis data penelitian ni, yaitu (1) reduksi data, (2) penyajian data, dan (3) penarikan kesimpulan.

Kemudian setelah analisis data, langkah selantutnya adalah pengecekan keabsahan data Pengecekan keabsahan data merupakan kegiatan memeriksa tentang keabsahan data yang telah didapat. Peneliti melakuakan pengecekan keabsahan temuan data dengan cara triangulasi, pengecekan anggota, perpanjangan waktu pengamatan, meningkatkan ketekunan, dan kecukupan bahan referensi.

\section{HASIL DAN PEMBAHASAN}

Hasil

Pelaksanaan kegiatan membaca setiap pagi bagi siswa tunarungu di SLB Eka Mandiri Batu merupakan program sekolah yang dilaksana sebelum pelajaran dimulai. Kegiatan ini mengacu pada program literasi yang sudah diprogramkan dari pemerintah. Proses kegiatan membara setiap pagi ini dilaksanakan 15 menit sebelum kegiatan pembelajaran dimulai. Buku bacaan yang digunakan dalam kegiatan in tidak hanya buku yang bersifat formal seperti buku pelajaran, namun juga menggunakan buku-buku yang disenangi oleh siswa-siswi tunarungu, seperti buku cerita pendek, buku belajar membaca, dan buku-buku yang lainnya. Selain itu, kegiatan membaca setiap pagi ini juga disesuaikan dengan tingkat kelasnya. Ini dilakukan karena siswa-siswi tunarungu memiliki tingkat kecerdasan yang berbeda-beda diantara siswa kelas rendah (kelas 1-4) dengan siswa kelas tinggi (kelas 5-6)

Pelaksanaan kegiatan membaca pada kelas rendah dimulai dengan kegiatan berdo'a bersama-sama. Setelah itu guru memberikan kesempatan kepada mereka untuk membaca di tempat masing-masing terlebih dahulu, hal ini bertujuan agar mereka dapat mengenal don memahami terlebih dahulu apa yang mereka baca. Setelah siswa tunarungu membaca di empat masing-masing, guru memberikan kesempatan siswa tunarungu untuk membaca di depan kelas secara bergantian. Dalam hal ini siswa dibiasakan 
untuk membaca dengan nyaring. Guru membenarkan bacaan dan pengucapan siswa apabila salah. Guru juga menjelaskan maksud dari kata yang dibaca siswa agar anak mengerti arti dari kata tersebut. Hal ini bertuju agar selain bisa membaca dan menggunakan bahas oral, siswa tunarungu juga bisa mengerti arti kata yang telah dibacanya.

Sedikit berbeda dengan pelaksanaan kegiatan membaca pada kelas rendah. Pada pelaksanaan kegiatan membaca di kelas tinggi, ketika ada salah satu siswa membaca di depan kelas, bukan hanya guru yang menyimak bacaan siswa, melainkan siswa lain juga menyimak dan harus bisa membaca gerak bibir temannya. Hal ini bertujuan untuk melatih siswa dala hal membaca gerak bibir.

Ada 2 hambatan dalam pelaksanaan kegiatan membaca setiap pagi dalam upaya meningkatkan kemampuan oral siswa tunarungu di SLB Eka Mandiri, yaitu hambatan internal dan hambatan eksternal. Hambatan internal ini adalah hambatan yang berasa dari diri siswa itu sendiri. Contoh dari hambata internal adalah tingkat kecerdasan siswa yang rendah. Sedangkan hambatan eksternal ini adalah hambatan yang berasal dari luar diri siswa tunarungu itu sendiri. Hambatan tersebut meliputi: 1) buku yang kurang mendukung, 2) waktu yang digunakan dalam kegiatan ini terlalu singkat, dan 3) kurangnya dukungan oran tua di rumah. Banyak ditemukan orang tua yang tidak peduli dengan kegiatan belajar anak di rumah, mereka lebih cenderung menyerahkan secara penuh proses belajar anak mereka ke sekolah tanpa adanya dukungan belajar di rumah.

Dampak Kegiatan Membaca

Salah satu dampak dari kegiatan membaca ini adalah siswa-siswi tunarungu lebih bera berknani lion lam hal berkomunikasi dengan orang hin ini jug berdampak pada jumlah teman yang merek miliki semakin banyak. Dampak lain dari kegitmn mema setiap pagi pada iswa torungu di SLB Eka Mand setu ini adalah mereka lebih sering ma Mandi bahasa oral dalam kegiatan pembelajaran.

Kegiatan membaca setiap pagi ini juga memiliki dampak yang cukup bagus dalam kehidupan anak rumah. Sebagaimana kita tahu, untuk berkomunikas mon dalm kehidupn schar hari kebanykan ong

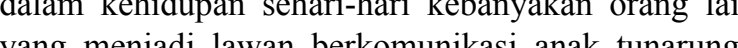
tidak ment lebih mengert ata memahom ap yang dicampik he hak tun bibir atau bas ora Dengan kemampuan oral akibat dari kegiatan membec, a tunarungu lebih banyak mengennakn bahasa dalam berkomunikasi.

\section{Pembahasan}

Bedasarkan hasil temuan peneliti di SLB Eka Mandiri Batu tujuan dari kegiatan membaca setia pagi yang dilaksanakan adalah untuk meningkatkan siswa dibiasakan untuk meng. Dalam kegiatan in siswa dibiasakan untuk membaca dengan suara yang nyaring. Dengan no baca nyang tersebut dharapkan kemampuan oral siswa tunarungu meningkat, terutam dalan hal pengucapan dan gerak bibinya. Menury (2011), da 9 tujan muns d (19), dalam Rum (2011), ada 9 tujum nownoca, diantara tujuannyaring, dan menggunakan setrategi tertentu.

Pada kegiatan membaca setiap pagi dalam upaya meningkatkan kemampuan oral siswa tunarungu SLB Eka Mandiri Batu juga menggunakan setrategi tertentu, setrategi ini digunakan untuk mencapa tujuan. Dalam kegiatan membaca setiap pagi di SLB Eka Mandiri Batu ditemukan perbedaan strategi dalam pelaksanaan kegiatan membaca pada kelas renda dan kelas tinggi. Hal ini dilakukan karena tingka swa kelas rendah dan as tinggi berbeda.

Menurut Kamus Besar Bahasa Indonesia (2016), yang dimaksud dengan hambatan adalah halangan, rintangan. Berdasarkan temuan peneliti, ada 2 hambata dalam pelaksanaan kegiatan membaca setiap pag dalam upaya meningkatkan kemampuan oral siswa tunarungu di SLB Eka Mandiri Batu, yaitu hambata internal dan hambatan ekstenal. Hambatan interna ini adalah hambatan yang berasal dari diri siswa itu sendiri, seperti tingkat kecerdasan siswa yang rendah Keadaan tersebut mengakibatkan mereka mengalan Kebanyakan dari mereka tidak hafal akan huruf.

Sedangkan hambatan eksternal adalah hambatan yang berasal dari luar diri siswa tunarungu itu sendiri. Hambatan tersebut meliputi. 1) buku yang kurang mendukung, 2) waktu yang digunakan dalam kegiatan ini terlalu singkat, dan 3) kurangnya dukungan oran tua di rumah. Banyak ditemukan orang tua yang tidak peduli dengan kegiatan belajar anak di rumah, merek tidak pernah mengajak anak mereka untuk belaja bersama, misalnya dengan kegiatan membaca, merek lebih cenderung menyerahkan secara penuh proses belajar anak mereka ke sekolah tanpa adanya dukungan belajar di rumah. Dari hasil penelitian Morrow da Young (1997), dalam Sandjaja (2001), menemukan bahwa kegiatan membaca bersama antara anak da orang tuanya berpengaruh terhadap sikap dan mina membaca anak.

Kurang pedulinya orang tua terhadap kegiatan belajar anak ini disebabkan oleh beberapa faktor, salah satunya adalah status sosial ekonomi orang tua yang rendah. Slavin (1998), dalam Sandjaja (2001:5), menemukan adanya perbedaan aktivitas orang tu dalam membimbing anak antara keluarga denga status ekonomi tinggi dengan status ekonomi rendah. Dampak Kegiatan Membaca

Menurut Kamus Besar Bahasa Indonesia (2016), dampak adalah pengaruh kuat yang mendatangkan akibat (baik negatif maupun positif). Salah satu dampak dari kegiatan me di SLB Eka Mandiri Batu adalah siswa-siswi tunarungu lebih berani berkomunikasi diswa-sisw tharungu lebih ben benk hank dengan orang Hal ini berdampak baik terhadap siswa tunarungu, mereka jadi lebih banyak mempunyai teman. Rahardja (2004), menjelaskan bahwa komunikasi digunakan untuk menyampaikan informasi. Apabila seseorang berkomunikasi dengan orang lain, sebenarnya dia menyampaikan informasi. Orang yang menerim informasi akan memberikan reaksi atau respon sehingga terjalinlah hubungan interaksi antara kedua orang terjsebut. Menurut Geniofam (2010) dalam Ayudani \& Setiadi, mengemukakan bahwa untuk berkomunikasi dengan orang lain, anak tunarungu menggunakan bahasa bibir atau bahasa isyarat. Namun faktanya dalam kehidupan sehari-hari kebanyakan orang lain yang menjadi lawan berkomunikasi anak tunarungu tidak mengerti akan bahasa isyarat, mereka cenderung lebih mengerti atau memahami apa yang disampaikan oleh anak tunarungu dengan menggunakan bahasa bibir. Hal ini mengakibatkan anak tunarungu yang kurang bisa menggunakan bahasa bibir atau bahasa oral lebih cenderung diam dan tidak berani berkomunikasi ketika bertemu dengan orang lain.

Dampak lain dari kegiatan membaca setiap pagi dalam upaya meningkatkan kemampuan oral siswa tunarungu di SLB Eka Mandiri Batu adalah mereka lebih sering menggunakan bahasa oral dalam kegiatan pembelajaran. Tidak sampai disitu, berdasarkan hasil wawancara yang telah dilakukan terhadap salah satu wali murid diketahui bahwa penggunaan bahasa oral yang digunakan siswa tunarungu di rumah juga mengalami peningkatan. Mereka lebih sering dengan menggunakan bahasa oral.

\section{KESIMPULAN DAN SARAN}

\section{Kesimpulan}

Kegiatan membaca pada siswa tunarungu di SLB Eka Mandiri Batu dilaksanakan kurang lebih 15 menit sebelum kegiatan pembelajaran dimuali. Pelaksanaan kegiatan ini disesuaikan dengan kemampuan siswa. Tujuan dari kegiatan ini adalah untuk melatih Tiswa tunarungu.

Banyak ditemukan hambatan dalam kegiatan (2) hambatan eksternal. Contoh dari hambatan internal adalah tingkat hambtan eksternal adalah buku bacaan yang kurang memadai, kurangnya waktu yang digunakan, dan kurangnya dukungan dari orang tua.

Dampak dari kegiatan membaca pada siswa tunarungu dapat dilihat dari jumlah teman yang dimilikinya. Semakin meningkat kemampuan oral siswa maka jumlah teman yang dimilikinya semakin banyak. Hal ini dikarenakan dengan peningkatan kemampuan oral, maka keberanian siswa tunarungu untuk berkomunikasi dengan orang lain tidak mengalami hambatan pendengaran semakain meningkat juga.

Saran

Kegiatan membaca setiap pagi memiliki banyak mek terhadap siswa tunarungu, oleh karena itu sebaiknya waktu yang digunakan dalam kegiatan ni lebih banyak. Selain itu buku bacaan yang digunakan dalam kegiatan ini sebaiknya dilengkapi dan disesuaikan dengan kemampuan anak. Kemudian sebaiknya kegiatan membaca setiap pagi diberi nama, sehingga lebih menarik bagi siswa dalam mengikutinya.

\section{DAFTAR RUJUKAN}

Ayudani, Cahaya M \& Setiadi.(Tt) Tanpa tahun. Efektifitas Speeh Therapy Terhadap Peningkatan Kemampuan Berbahasa pada Anak Tunarungu di TK Luar Biasa Karya Mulia Surabaya. (On php?f=Manuscript\%20pdf.pdf), diakses pada 21 php?:=Manuscript

Kamus Besar Bahasa Indonesia (KBBI). (2016). (Online). (http://kbbi.web.id/dampak), diakses pada 19 April 2017.

Kamus Besar Bahasa Indonesia (KBBI). (2016). (Online). (http://kbbi.we.id/hambatan), diakses pada 19 April 2017.

Moleong, L J (2016). Metodologi Penelitian Kualitatif. Bandung: PT Remaja Rosdakarya

Muhammad, J. K. A. (2008). Panduan Pendidikan Khusus Anak-anak dengan Ketunaan dan Learning Disabilities. Jakarta: PT Mizan Publika.

Rahardja, A T. (2004). Hubungan Antara Komunikasi Antar Pribadi Guru dan Motivasi Kerja Guru dengan Kinerja Guru SMUK BPK PENABUR Jakarta. Jurnal Pendidikan Penabur, 3 (3). (Online), (http://bpkpenabur.orid/wp-content/ uploads/2015/10/jurnal-No03-III-Desember2004. pdf\#page=119), diakses pada 10 Mei 2017

Rahim, F. (2011). Pengajaran Membaca di Sekolah Dasar. Jakarta: Bumi Aksara. 
Sandjaja, S. (Tt). Pengaruh Keterlibatan Orang Tua Terhadap Minat Membaca Anak Ditinjau dari Pendekatan Stres Lingkungan. (Online). diakses pada 20 April 2017

Somantri, S. (2012). Psikologi Anak Luar Biasa. Bandung: Refika Aditama.
Ulfatin, N. (2014). Metode Penelitian Kualitatif di Bidang Pendidikan: Teori dan Aplikasinya. Malang: Bayumedia Publishing.

Undang-Undang Republik Indonesia Nomor 20 Tahun 2003 Tentang Sistem Pendidikan Nasional. Pusat Data dan Informasi Pendidikan. Jakarta: Balitbang Depdiknas. (Online), (http://pendis.kemenag. go.id), diakses 01 Desember 2016. 